\title{
Expression of Endochitinase from Trichoderma harzianum in Transgenic Apple Increases Resistance to Apple Scab and Reduces Vigor
}

\author{
Jyothi Prakash Bolar, John L. Norelli, Kwai-Weng Wong, Christopher K. Hayes, \\ Gary E. Harman, and Herb S. Aldwinckle
}

First, second, third, and sixth authors: Department of Plant Pathology; fourth and fifth authors: Department of Horticultural Sciences, Cornell University, New York State Agricultural Experiment Station, Geneva 14456.

Current address of C. K. Hayes: BioWorks, Inc., 122 North Genesee Street, Geneva, NY 14456.

Accepted for publication 25 August 1999.

\section{ABSTRACT}

Bolar, J. P., Norelli, J. L., Wong, K.-W., Hayes, C. K., Harman, G. E., and Aldwinckle, H. S. 2000. Expression of endochitinase from Trichoderma harzianum in transgenic apple increases resistance to apple scab and reduces vigor. Phytopathology 90:72-77.

The goal of this research was to improve scab resistance of apple by transformation with genes encoding chitinolytic enzymes from the biocontrol organism Trichoderma harzianum. The endochitinase gene, as cDNA and genomic clones, was transferred into apple cv. Marshall McIntosh by Agrobacterium-transformation. A total of 15 lines were identified as transgenic by NPTII enzyme-linked immunosorbent assay and polymerase chain reaction and confirmed by Southern analysis. Substantial differences in endochitinase activity were detected among differ- ent lines by enzymatic assay and western analysis. Eight lines propagated as grafted and own-rooted plants were inoculated with Venturia inaequalis. Six of these transgenic lines expressing endochitinase were more resistant than nontransformed cv. Marshall McIntosh. Disease severity compared with cv. Marshall McIntosh was reduced by 0 to $99.7 \%$ (number of lesions), 0 to $90 \%$ (percentage of leaf area infected), and 1 to $56 \%$ (conidia recovered) in the transgenic lines tested. Endochitinase also had negative effects on the growth of both inoculated and uninoculated plants. There was a significant negative correlation between the level of endochitinase production and both the amount of disease and plant growth.

Additional keyword: Malus $\times$ domestica.
McIntosh is the most widely grown apple cultivar in the northeastern United States (13). Most commercially important apple cultivars, including McIntosh, are very susceptible to apple scab (32). Apple scab, caused by the fungus Venturia inaequalis (Cooke) G. Wint., is the most widespread disease in apple orchards worldwide $(2,31)$. The ascospores germinate on leaf or fruit surfaces in the presence of free moisture. After formation of an appressorium and a penetration peg, the pathogen penetrates the cuticle and becomes established between the epidermis and the cuticle. It ramifies into a subcuticular stroma, which eventually produces conidiophores and conidia, usually resulting in visible lesions. Disseminated conidia can germinate, penetrate the host, and give rise to new lesions. Disease increases by repeated cycles of infection by conidia (31). This disease is responsible for a large proportion of the chemical fungicides applied to apples. However, chemical control has been challenged by the development of resistance in $\mathrm{V}$. inaequalis to some fungicides $(15,21,24)$.

Although scab-resistant apple cultivars (e.g., Liberty and Florina) have been bred by introgressing the $V f$ gene for scab resistance from the small fruited crabapple Malus floribunda clone 821 into Malus $\times$ domestica (25), these cultivars are not commercially successful, in part due to insufficient fruit quality. In Europe, new races of $V$. inaequalis have overcome the $V f$ resistance gene (37). Unlike many crops, apples are sold by name and name recognition is important in marketing. Genetic engineering can be used to improve existing cultivars while maintaining the cultivar's charac-

Corresponding author: H. S. Aldwinckle;

E-mail address: hsa1@ nysaes.cornell.edu

Publication no. P-1999-1111-01R

(C) 2000 The American Phytopathological Society ters. Increasing scab resistance of commercial apple cultivars would significantly reduce the use of chemical fungicides and provide economic benefits to apple growers.

In response to pathogen attack, plants activate a variety of defense-related genes, including chitinases $(7,26)$. These enzymes hydrolyze chitin-containing fungal cell walls and are presumed to play a major role in plant defense response. Chitin constitutes the main component of the cell wall polysaccharides of most fungal taxa, including the loculoascomycetes to which $V$. inaequalis belongs $(22,44)$. Several plant chitinases have been cloned (12), and transgenic plants (e.g., rice, tobacco, canola, tomato, and cucumber) constitutively overexpressing plant chitinases have been produced as a strategy to increase resistance to fungal pathogens, with varying levels of protection $(12,40)$. There is a possibility of breakdown of resistance on chitinase transgenic plants. However, compared to race-specific resistance, where the resistance $(\mathrm{R})$ gene plays a major role in the initial event of recognition response, the chitinase would act on an essential component of the cell wall of the pathogen.

Fungal cell-wall degrading enzymes (endochitinase, chitobiosidase, $N$-acetyl- $\beta$-D-glucosaminidase, and glucan 1,3 - $\beta$-glucosidase) from the biocontrol fungus Trichoderma harzianum have been characterized $(19,27,28)$. Purified enzymes from T. harzianum are substantially more antifungal than chitinolytic and glucanolytic enzymes reported from plants and other sources and are active on a much wider range of pathogens $(27,28,30)$.

In vitro testing has shown $T$. harzianum chitinases to be active against the apple pathogens $V$. inaequalis and Gymnosporangium juniperi-virginianae Schwein. (42). The gene coding for the $T$. harzianum endochitinase (ThEn-42, ech42) has been cloned (20), and substantially similar genes have been cloned from other strains of $T$. harzianum $(9,17)$. Endochitinase codes for a 424-amino acid 
protein, in which the first $26 \mathrm{~N}$-terminal amino acids code for a signal peptide that is responsible for extracellular secretion of the enzyme. Constitutive expression of this $T$. harzianum endochitinase has been demonstrated in tobacco and potato, and the transgenic lines showed a high level of resistance against a broad spectrum of diseases (30). In these transgenic plants, the T. harzianum signal peptide was correctly cleaved and extracellular accumulation of the fungal enzyme was induced, suggesting that signal sequences from fungi may be used to secrete fungal enzymes in plants (30).

The goal of this research was to produce transgenic 'Marshall McIntosh' apple lines expressing endochitinase (ech42) to evaluate the enzyme's effect on the susceptibility of apple to $V$. inaequalis.

\section{MATERIALS AND METHODS}

Plasmid binary vectors. The genetic sequence of endochitinase was described by Hayes et al. (20). A full-length copy of the genomic DNA was amplified from total DNA of T. harzianum strain $\mathrm{P} 1$ by polymerase chain reaction (PCR), and inserted into pCRII (Stratagene, La Jolla, CA) using the manufacturer's directions. The resulting plasmid was first digested with $B a m \mathrm{HI}$ and later partially digested with EcoRI, and ligated into the BamHI-EcoRI digested binary vector pBI121 (Clontech Laboratories Inc., Palo Alto, CA). The resulting plasmid was designated p35S-ThEn42 (Fig. 1A).

For stronger expression of ech42, plasmid pBIN19ESR was constructed (Fig. 1B). The complete cDNA sequence of endochitinase was amplified from the cDNA library of $T$. harzianum strain P1 (library was constructed by Stratagene) using the NcoS forward primer (5'-GTCGTAC ${ }^{\prime}$ CATGGTGGGCTTCCTCGGAAAATC$\left.3^{\prime}\right)$ and NcoR reverse primer (3'-CAGTACGGTAC'CGAGGGACGTATTAGCAAAGCG-5'). The resulting PCR fragment was restriction digested with $\mathrm{NcoI}$ (restriction sequence underscored), and cloned into the NcoI site of pBI525 (obtained from W. Crosby, Plant Biotechnology Institute, Saskatoon, Saskatchewan, Canada). The creation of NcoI restriction sequences in the amplified endochitinase gene necessitated a $\mathrm{T}$ to $\mathrm{G}$ change in the fourth base from the start of the initiation codon, resulting in the change of the codon for leucine (TTG) into valine (GTG). Because both amino acids were aliphatic, hydrophobic, and neutral in charge, little change was expected in the secondary structure and physiological function of the enzyme. The entire cassette between the HindIII and EcoRI sites of pBI525 (CAMV 35S-35S, AMV leader sequence, ech42 and nos terminator) was ligated into the binary vector pBIN19 (1) that had been cut by the HindIII-EcoRI restriction enzymes. The resulting plasmid was designated pBIN19ESR. Plasmids p35S-ThEn42 and pBIN19ESR were transferred to Agrobacterium tumefaciens strain EHA105 (obtained from S. Gelvin, Purdue University, West Lafayette, IN) using the procedure described by Nagel et al. (33).

Plant tissue culture and transformation. Apple cv. Marshall McIntosh was transformed. Methods and media used for shoot-tip proliferation, inoculum production, inoculation of wounded leaves, cocultivation of inoculated leaves, and plant regeneration have been described previously (3,35). Leaf segments of cv. Marshall McIntosh were inoculated with A. tumefaciens strain EHA105 containing the plasmid pBIN19ESR or p35S-ThEn42 and independent transgenic lines were recovered as described previously (3).

PCR analysis. DNA was isolated from the youngest leaf of putative transgenics and nontransformed control plants as described by Cheung et al. (11) and the PCR procedure was as described previously (3). PCR was conducted using primers specific for ech42 and $n p t$ II genes (Fig. 1). With primers specific to $\operatorname{vir} G$ (10), a band was detected only for the plasmid control pAL4404, indicating that the transgenic plants were not contaminated with A. tumefaciens.

Enzyme-linked immunosorbent assay for nptII protein. The amount of nptII protein in the putative transgenic leaf tissue samples was determined using a standard sandwich enzyme-linked immunosorbent assay (ELISA) according to manufacturer's recommended procedure (5Prime $\rightarrow$ PPrime Inc., Boulder, CO).

Southern analysis. DNA was extracted from the leaf tissue of nontransformed and putative transgenic plants (16), and Southern analysis was performed using standard procedures from directions in Genescreen Plus (NEN Research Products, Boston). Probes were the nptII (750 bp) and ech42 (1,300 bp) coding regions labeled with ${ }^{32} \mathrm{P}$ using random primers (14).

Western analysis. Individual leaves from transgenic and control lines were processed as described by Gegenheimer (18). The ratio of extraction buffer to plant material was kept constant, and equal amounts were loaded onto the gel. Purified 42-kDa endochitinase from T. harzianum was used as a standard, and a BenchMark prestained protein ladder (Life Technologies, Grand Island, NY) was used as a molecular weight marker. Sodium dodecyl sulfate-polyacrylamide gel electrophoresis (SDS-PAGE) was performed with $12 \%$ resolving gel and 5\% stacking gel in a Miniprotean II cell assembly (Bio-Rad Laboratories, Hercules, CA). The protein was transferred onto the Immobilon-Psq membrane (Millipore, Bedford, MA) using a Mini Trans-Blot Electrophoretic Transfer Cell (Bio-Rad). The protein was detected using the primary polyclonal antibody specific to endochitinase from rabbit. Antirabbit immunoglobulin (Ig; Amersham) was used as the secondary antibody, and immunodetected using equivalent chain length (ECL) western detection reagents (Amersham Life Science).

Activity assay for endochitinase. Endochitinase activity was detected and quantified using a modification of the procedure described by Tronsmo and Harman (41). Leaf tissue (10 to $15 \mathrm{mg}$ ) was ground in assay buffer (50 $\mu \mathrm{l}$ of leaf tissue per $\mathrm{mg}$; buffer consisted of $1 \mathrm{ml} 10 \%$ of SDS, $1 \mathrm{ml}$ of $10 \%$ Triton X-100, $2 \mathrm{ml}$ of sodium EDTA [0.5 M], $70 \mu \mathrm{l}$ of mercaptoethanol [14.4 M], and $96 \mathrm{ml}$ of sodium acetate buffer [100 mM], pH 5.0). Ground extract $(100 \mu \mathrm{l})$

\section{A p35S-ThEn42}

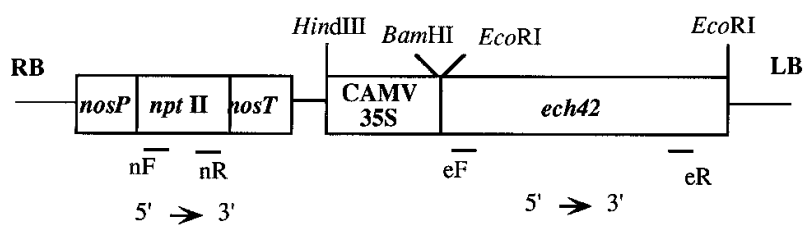

B pBIN19ESR

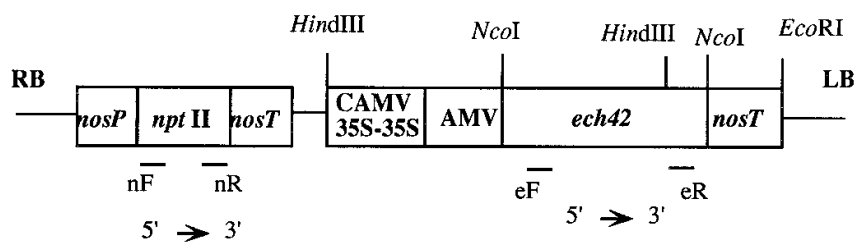

Fig. 1. T-DNA of A, plasmid p35S-ThEn42 containing the genomic DNA of ech42 (including 3 introns totaling $194 \mathrm{bp}$ ) with its own terminator; B, plasmid pBIN19ESR containing the cDNA of ech42 (1,366 bp). NosP, nos promoter (305 bp); nosT, nos terminator (250 bp); nptII, neomycin phosphotransferase II encoding gene (794 bp); CAMV-35-35S, enhanced cauliflower mosaic virus $35 \mathrm{~S}$ promoter ( $620 \mathrm{bp}$ ); AMV, alfalfa mosaic virus leader sequence (44 bp); and CAMV-35S, CAMV 35S promoter $(800 \mathrm{bp})$. Approximate positions of primers used for polymerase chain reaction analysis: for the nptII gene, a forward primer $\mathrm{nF}$ (5'-ACAAGATGGATTGCACGCAGG-3') and reverse primer $\mathrm{nR}$ ( $5^{\prime}$-AACTCGTCAAGAAGGCGATAG-3') were used; for the $e c h 42$, gene a forward primer eF (5'-GCCAGTGGATACGCAAACGC- $\left.3^{\prime}\right)$ and reverse primer eR (5'-CTCTAGTTGAGACCGCTTC-3') were used. Restriction endonuclease sites: H, HindIII; N, NcoI; E, EcoRI; and B, BamHI. 
was mixed with $40 \mu \mathrm{l}$ of substrate 4-methylumbelliferyl- $\beta$-D- $N, N^{\prime}, N^{\prime \prime}$ triacetylchitotrioside $(1 \mathrm{mg}$ of substrate dissolved in $3.5 \mathrm{ml}$ of sodium acetate buffer [100 mM, pH 5.0]; Sigma Aldrich Chemical Co., St. Louis]. The reaction was stopped at 15 -min intervals with 0.2 M sodium carbonate in CytoFluor II plates (Perseptive Biosystems, Framingham, MA), and fluorescence was determined at 360/460 (excitation/emission) with a CytoFluor II fluorescence multiwell plate reader as recommended by the manufacturer (Perseptive Biosystems). Fluorescence of known concentrations of 4-methylumbelliferone (Sigma) was used to plot a standard curve to determine the activity of endochitinase present in the samples tested. The amount of protein in the leaf sample was determined using the Bio-Rad Bradford dye-binding protein assay as recommended by the manufacturer (Bio-Rad). The activity of endochitinase was defined as nanomolar methylumbelliferone released per minute per microgram of protein.

Evaluation of disease resistance and plant growth. To screen for scab resistance, eight transgenic lines that had varying levels of endochitinase expression, designated as T560 to T566 and T568, were selected. Nontransformed cv. Marshall McIntosh, T286 (pBI121 transgenic Marshall McIntosh line that does not contain the ech42 gene) (3), and resistant cv. Liberty, were used as controls. Cv. Liberty carries the $V f$ dominant gene for resistance to $V$. inaequalis (25). Tissue culture plants were either own-rooted (4) or micrografted onto seedling rootstocks. To produce micrografted plants, potted seedlings were established for 1 month and cut back to 15 to $20 \mathrm{~cm}$. Single shoot tips (10 to $15 \mathrm{~mm}$ ) from proliferation cultures were inserted into the bark of the seedlings, tied with parafilm, and covered with microfuge tubes to maintain humidity. The tubes were opened 1 week later. Own-rooted plants were maintained in a growth chamber and the micrografts in the greenhouse.
The youngest expanded leaf was tagged and the plants were inoculated with a conidial suspension $\left(10^{6}\right.$ conidia per $\left.\mathrm{ml}\right)$ that included a mixture of races 1 to 5 of $V$. inaequalis (isolates 1805-2, 1770-8, 1771-2, 1778-6, and 1810-1), using an atomizer connected to compressed air supply (43). The isolates were originally obtained from E. B. Williams (Purdue University). The plants were incubated in a mist chamber (16-h photoperiod of $40 \mu \mathrm{mol} / \mathrm{m}^{2} / \mathrm{sec}$, $18 \pm 1{ }^{\circ} \mathrm{C}$, and $100 \%$ relative humidity) for $48 \mathrm{~h}$ and later moved to a growth chamber or greenhouse. At $\approx 2$ weeks after inoculation, the severity of the disease was recorded from four leaves (the tagged leaf, one leaf above, and two leaves below the tagged leaf). Data were recorded as numbers of sporulating lesions, the percentage of leaf area infected, and conidia from the four leaves. To evaluate the vigor of both the inoculated and uninoculated plants, data were collected on the height of the plants from the soil line (ownrooted) or from the graft union (micrografts) to the terminal leaf, number of nodes (leaves), and a qualitative estimate of the degree of chlorosis. The conidial count data were transformed to natural logarithms and subjected to analysis of variance (ANOVA). Data were analyzed using the SAS (Cary, NC) general linear model procedure.

\section{RESULTS}

Plasmid binary vectors. Both the genomic (p35S-ThEn42) and cDNA (pBIN19ESR) binary vectors contained the native signal peptide from T. harzianum. The endochitinase gene in p35S-ThEn42 has three introns and the native polyadenylation terminator signal from $T$. harzianum, and the gene is under the control of the cauliflower mosaic virus 35S (CAMV 35S) promoter. pBIN19ESR contains an enhanced cauliflower mosaic virus 35S (CAMV 35S-
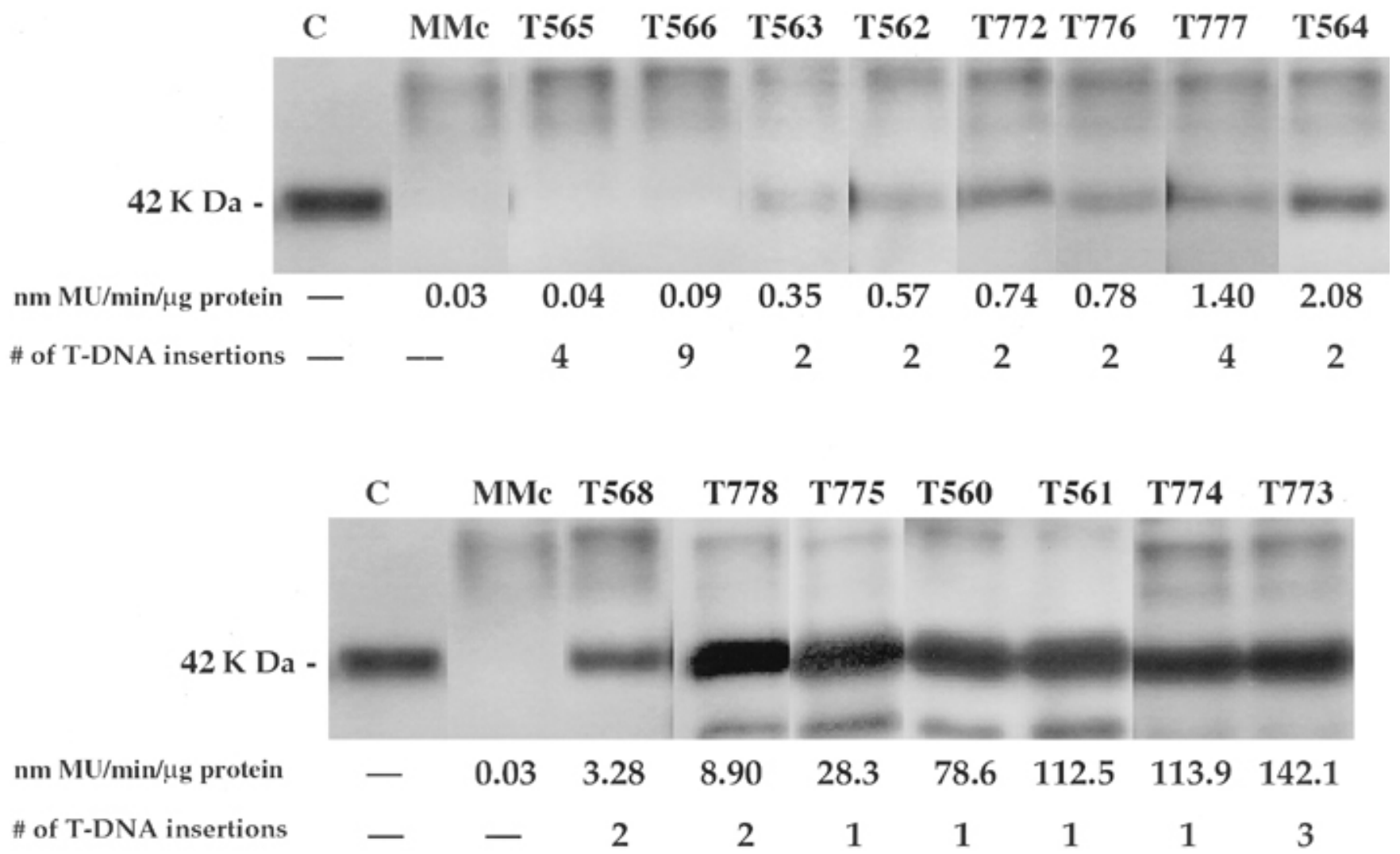

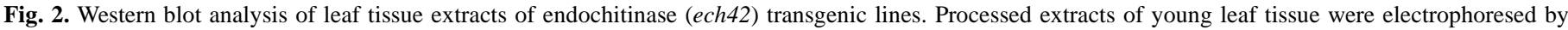

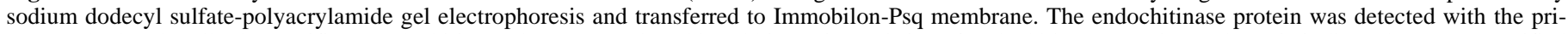

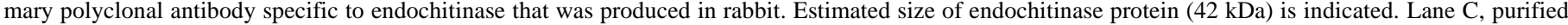

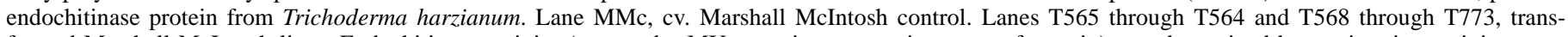

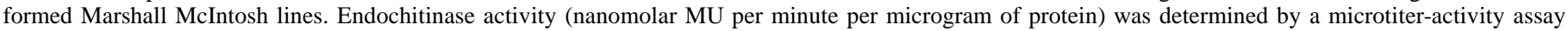
using the substrate 4-methylumbelliferyl- $\beta$-D- $N, N^{\prime}, N^{\prime \prime}$-triacetylchitotrioside. Results from Southern blot analysis indicate the number of T-DNA insertions. 
35S) promoter (36), an alfalfa mosaic virus (AMV) RNA4 untranslated leader, a sequence which directs high translational efficiency (23), and a nos terminator. Both the binary vectors carried the plant $n p t$ II gene as the selectable marker (Fig. 1).

Recovery of transgenic lines. T-DNAs (Fig. 1) from the two binary vectors (p35S-ThEn42 and pBIN19ESR) were introduced into leaf segments of cv. Marshall McIntosh by an Agrobacterium sp.mediated transformation system. The recovered regenerants were selected in the presence of paromomycin sulfate. Individual aminoglycoside-resistant plants were tested for the presence of T-DNA by PCR with primers specific for the ech 42 and $n p t I I$ coding regions (Fig. 1). The DNA was amplified in 2 lines transformed with genomic DNA of endochitinase (T565 and T566) and 13 lines transformed with cDNA of endochitinase (T560 to T564, T568, and T772 to T778). No band was detected in nontransformed cv. Marshall McIntosh (data not presented). Compared to the control, all of the lines tested produced higher levels of nptII protein (data not presented). Southern analysis of all the 15 putative transgenics lines with ech 42 and $n p t I I$ as probe confirmed the integration of the TDNA into the genome of the plants. The number of T-DNA fragments integrated into the genome of the plants ranged from one to nine (Fig. 2).

Characterization of endochitinase in transgenic lines. Western analysis indicated the presence of endochitinase in all of the transgenic lines but not in nontransformed cv. Marshall McIntosh (Fig. 2). A strong 42-kDa endochitinase band and an additional smaller band ( $31 \mathrm{kDa}$ ) were detected in the lines T778, T775, T560, T561, T774, and T773. The 31-kDa band may be a degradation product of $42-\mathrm{kDa}$ endochitinase. A single $42-\mathrm{kDa}$ band was detected in lines T563, T562, T772, T776, T777, T564, and T568, and a faint band was detected in T565 and T566. Two high molecular weight bands, specific for apple, cross-reacted with the antibody. To our knowledge, nothing is known so far as to the presence of proteins in apple with sequence homology to ech42.

The quantity of endochitinase was determined by a microtiteractivity assay using the substrate 4-methylumbelliferyl- $\beta$-D- $N, N^{\prime}, N^{\prime \prime}$ triacetylchitotrioside (Fig. 2). There was a strong relationship between the microtiter-activity assay for endochitinase and the western analysis (Table 1 and Fig. 2). Transgenic lines T565, T566, T563, T562, and T772 were not significantly different from the nontransformed cv. Marshall McIntosh control in microtiter-activity assay but had a faintly visible endochitinase protein band in western blot

TABLE 1. Evaluation of disease resistance of own-rooted transgenic cv. Marshall McIntosh lines 14 days after inoculation with a conidial suspension of Venturia inaequalis

\begin{tabular}{lcccc}
\hline $\begin{array}{l}\text { Transgenic } \\
\text { line }\end{array}$ & $\begin{array}{c}\text { ThEn-42 } \\
\text { activity }^{\mathrm{w}}\end{array}$ & $\begin{array}{c}\text { No. of } \\
\text { lesions }^{\mathrm{x}}\end{array}$ & $\begin{array}{c}\text { \% Area of } \\
\text { infection }^{\mathrm{x}}\end{array}$ & $\begin{array}{c}\text { Conidia } \\
\text { recovered }^{\mathrm{x}}\end{array}$ \\
\hline MM $^{\mathrm{y}}$ & 0.03 & $71.8 \mathrm{a}$ & $57.5 \mathrm{a}$ & $248,833 \mathrm{a}$ \\
T286 (vector) $^{\mathrm{z}}$ & 0.02 & $79.6 \mathrm{a}$ & $58.4 \mathrm{a}$ & $275,182 \mathrm{a}$ \\
T566 & 0.09 & $71.6 \mathrm{a}$ & $51.8 \mathrm{a}$ & $139,526 \mathrm{a}$ \\
T565 & 0.04 & $61.6 \mathrm{ab}$ & $44.7 \mathrm{ab}$ & $266,400 \mathrm{a}$ \\
T563 & 0.35 & $37.0 \mathrm{bc}$ & $33.9 \mathrm{bc}$ & $10,900 \mathrm{ab}$ \\
T562 & 0.57 & $32.8 \mathrm{~cd}$ & $25.7 \mathrm{~cd}$ & $21,440 \mathrm{ab}$ \\
T568 & 3.28 & $15.8 \mathrm{c}-\mathrm{e}$ & $12.5 \mathrm{de}$ & $9,400 \mathrm{bc}$ \\
T561 & 112.50 & $17.3 \mathrm{de}$ & $10.0 \mathrm{de}$ & nd \\
T564 & 2.08 & $4.3 \mathrm{de}$ & $4.0 \mathrm{e}$ & $1,500 \mathrm{c}$ \\
T560 & 78.60 & $0.0 \mathrm{e}$ & $0.0 \mathrm{e}$ & $4,750 \mathrm{c}$ \\
Liberty & 0.01 & $0.0 \mathrm{e}$ & $0.0 \mathrm{e}$ & $0 \mathrm{~d}$ \\
\hline
\end{tabular}

${ }^{\mathrm{w}}$ ThEn-42 activity in nanomolar MU per minute per microgram of protein. Activity was determined by a microtiter-activity assay with 4-methylumbelliferyl- $\beta$-D- $N, N^{\prime}, N^{\prime \prime}$-triacetylchitotrioside as substrate.

${ }^{x}$ Data presented are the mean of four leaves per plant (5 to 17 plants per line). The conidial count data were transformed to natural logarithm and subjected to analysis of variance. Values followed by the same letter are not significantly different $(P=0.05)$, as determined by Waller-Duncan $K$ ratio $t$ test. The experiment was repeated twice; nd = not determined.

y Nontransformed cv. Marshall McIntosh.

z Transgenic cv. Marshall McIntosh line transformed with pBI121 that does not contain the endochitinase gene. analysis. Lines T776, T777, T564, T568, T778, T775, T560, T561, $\mathrm{T} 774$, and $\mathrm{T} 773$ had endochitinase activity significantly greater than the control, and a strong endochitinase protein band was detected by western blot analysis (Fig. 2).

Evaluation of disease resistance. At $\approx 10$ days after inoculation, sporulating lesions were seen on the leaves of nontransformed cv. Marshall McIntosh and the vector-transformed control, T286. The data (Table 1) are the means of 4 leaves from 5 to 17 plants per line, 14 days after inoculation. There was no significant difference among transgenic lines T565 and T566 and nontransformed cv. Marshall McIntosh and T286 when measured by the number of sporulating lesions, percentage of leaf area infected, and number of conidia recovered. Lines T563, T562, and T568 had moderate levels of disease, with significantly fewer lesions and less leaf area infected. Lines T561, T564, and T560 had similar levels of disease resistance and were not significantly different from cv. Liberty as measured by the number of sporulating lesions and percentage of leaf area infected. Line T560 had no visible lesions as observed by the naked eye, but conidia were recovered when the leaves were rinsed. The three parameters of disease severity (number of sporulating lesions, percentage of leaf area infected, and the number of conidia recovered) together gave a good comparison of
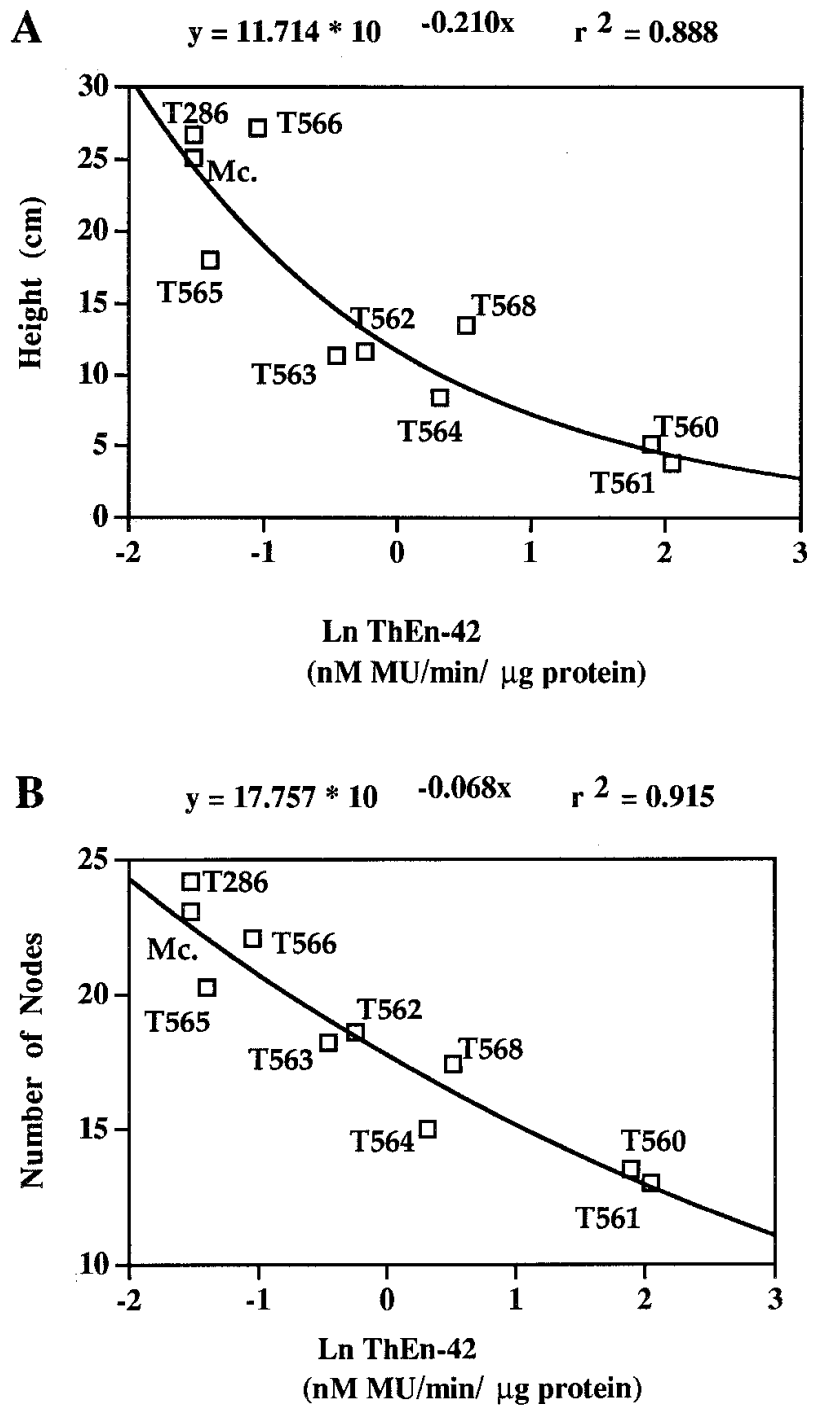

Fig. 3. Effect of endochitinase on growth of own-rooted transgenic cv. Marshall McIntosh lines. To evaluate plant growth, data were collected on $\mathbf{A}$, height of plants from the soil line and $\mathbf{B}$, number of nodes or leaves. Data were plotted against the natural logarithm $(\ln )$ of endochitinase activity (nanomolar MU per minute per microgram of protein). 
the transgenic lines. There was a negative correlation between endochitinase activity and number of lesions $\left(R^{2}=78 \% ; P=0.001\right)$, percent leaf area infected $\left(R^{2}=82 \% ; P=0.001\right)$, and number of conidia recovered $\left(R^{2}=72 \% ; P=0.004\right)$ (Table 1 and Fig. 2$)$.

Endochitinase activity and plant growth. To evaluate the influence of endochitinase activity on vigor of the plants, plant-growth parameters were recorded on both uninoculated and inoculated plants when disease data were collected. There was a negative correlation between endochitinase activity and plant height $(P=0.001)$ and the number of leaves $(P=0.001)$ (Fig. 3). Transgenic lines that showed a significant level of chitinase activity also showed a significant reduction in both plant height and number of leaves (Figs. 2 and 3). Lines T560 and T561, which had the greatest level of enzyme activity of the lines in Table 1 , were dwarf $(5.1$ and $3.8 \mathrm{~cm}$ tall respectively), rosetted with short internodes, and very chlorotic. Lines with a lower but statistically significant level of endochitinase activity (T563, T562, T564, and T568) had reduced growth but all had healthy green leaves. Grafted plants of the same lines had similar vigor as the own-rooted plants (there was a negative correlation between endochitinase activity and plant height $\left[R^{2}=81 \%\right.$; $P=0.001]$ and the number of nodes $\left.\left[R^{2}=92 \% ; \mathrm{P}=0.001\right]\right)$.

\section{DISCUSSION}

In this study, we recovered transgenic apple lines with varying levels of endochitinase expression (Fig. 2). Constitutive expression of fungal endochitinase in apple lines increased resistance to $V$. inaequalis. Disease severity compared with the nontransformed control was reduced by 0 to $99.7 \%$ (number of lesions), 0 to $90 \%$ (percentage of leaf area infected), and 1 to $56 \%$ (conidia recovered) in the transgenic lines tested (Table 1). The level of disease resistance was correlated with the level of endochitinase activity. However, because endochitinase activity also reduced plant growth, it is impossible to separate the effects of endochitinase on scab resistance from its effects on plant growth.

Several studies have reported that plant chitinases have a role in plant growth $(38,39)$, but the mechanism of growth inhibition in apple is thus far unknown. To test if the level of enzyme production had an effect on rooting, we compared the growth between the lines that were own-rooted and the same lines that were micrografted onto seedling rootstocks and found no difference in their growth pattern, suggesting that endochitinase had no direct effect on rooting. In transgenic solanaceous plants (tobacco and potato), even very high levels of expression of endochitinase had no deleterious effect upon plant growth (30). Data suggest that the reduction of vigor is a specific apple-T. harzianum endochitinase interaction. The same gene expressed in grape (J. Kikkert, personal communication), tobacco, and tomato (8) causes no reduction in plant vigor. Moreover, other chitinase genes expressed in a variety of plants also have no effect on plant growth $(12,40)$. In apple, expression of lytic peptides is not detrimental to plant growth (34).

One strategy to attain a high degree of resistance would be to pyramid endochitinase with other antifungal genes for complementary activities. Endochitinase interacts synergistically with other chitinolytic enzymes and cell membrane-affecting compounds that alter cell membrane structure or permeability of phytopathogenic fungi and bacteria (29). There is a strong in vitro synergistic interaction between very low levels of endochitinase and $\mathrm{N}$-acetyl$\beta$-D-glucosaminidase (ech42 and nag70, respectively) against fungal pathogens (28). We have, in fact, produced apple lines expressing $N$-acetyl- $\beta$-D-glucosaminidase and have observed no growth effects in apple (6). Presently, we are investigating the effect of pyramiding the genes endochitinase and $N$-acetyl- $\beta$-D-glucosaminidase in apple, to determine whether we can obtain high levels of resistance with minimal effect on plant growth (5). This strategy may also reduce the likelihood of resistance breakdown as a result of pathogen mutation and, hence, may be helpful for engineering broad, durable resistance.

\section{ACKNOWLEDGMENTS}

This research was funded in part by the New York State Apple Research and Development Program and the New York State Center for Advanced Technology Biotechnology Program. We thank B. Donzelli for providing endochitinase from $T$. harzianum used in this study.

\section{LITERATURE CITED}

1. Bevan, M. 1984. Binary Agrobacterium vectors for plant transformation. Nucleic Acids Res. 12:8711-8721.

2. Biggs, A. R. 1990. Apple scab. Pages 6-9 in: Compendium of Apple and Pear Diseases. A. L. Jones and H. S. Aldwinckle, eds. The American Phytopathological Society, St. Paul, MN.

3. Bolar, J. P., Brown, S. K., Norelli, J. L., and Aldwinckle, H. S. 1999. Factors affecting the transformation of 'Marshall McIntosh' apple by Agrobacterium tumefaciens. Plant Cell Tissue Organ Cult. 55:31-38.

4. Bolar, J. P., Hanke, V., Norelli, J. L., and Aldwinckle, H. S. 1998. An efficient method to root and acclimatize micropropagated apple cultivars. HortScience 33:1251-1252.

5. Bolar, J. P., Norelli, J. L., Aldwinckle, H. S., Harman, G. E., and Brown, S. K. 1998. Production of transgenic apple lines for scab resistance with genes coding for one or two chitinolytic enzymes. 7th Int. Congr. Plant Pathol. (Abstr.) ICPP-98 3:5.3.2.

6. Bolar, J. P., Norelli, J. L., Aldwinckle, H. S., Harman, G. E., and Brown, S. K. 1998. Expression of an exochitinase gene from Trichoderma harzianum in transgenic apple lines. (Abstr.) Phytopathology 88(suppl.):S8.

7. Boller, T. 1993. Antimicrobial functions of the plant hydrolases, chitinases and 1,3-glucanases. Pages 391-400 in: Mechanisms of Plant Defense Responses. B. Fritig and M. Legrand, eds. Kluwer Academic Press, Dordrecht, Netherlands.

8. Brants, A. 1999. Transformation of tobacco and tomato with a fungal endochitinase gene and assays for resistance to nematodes and fungi. Ph.D. dissertation. Cornell University, Ithaca, NY.

9. Carsolio, C., Gutierrez, A., Jimenez, B., Van Montagu, M., and HerreraEstrella, A. 1994. Characterization of ech-42, a Trichoderma harzianum endochitinase gene expressed during mycoparasitism. Proc. Natl. Acad. Sci. USA 91:10903-10907.

10. Chen, C. R., Wang. L., and Winans, S. 1991. Characterization of the supervirulent virG gene of the Agrobacterium tumefaciens plasmid pTiBO542. Mol. \& Gen. Genet. 230:302-309.

11. Cheung, W. Y., Hubert, N., and Landry, B. S. 1993. A simple and rapid DNA microextraction method for plant, animal, and insect suitable for RAPD and other PCR analyses. PCR Methods Appl. 3:69-70.

12. Collinge, D. B., Kragh, K. M., Mikkelsen, J. D., Nielsen, K. K., Rasmussen, U., and Vad, K. 1993. Plant chitinase. Plant J. 3:31-40.

13. Cranney, J. R. 1997. 1997-Apple crop outlook. Am. Fruit Grow. 117:7-8.

14. Feinberg, A. P., and Vogelstein, B. 1983. A technique for radiolabeling DNA restriction endonuclease fragments to high specific activity. Anal. Biochem. 132:6-13.

15. Fiacccadori, R., Gielink, A. J., and Dekker, J. 1987. Sensitivity to inhibitors of sterol biosynthesis in isolates of Venturia inaequalis from Italian and Dutch orchards. Neth. J. Plant Pathol. 93:285-287.

16. Fulton, T. M., Chunwongse, J., and Tanksley, S. D. 1995. Microprep protocol for extraction of DNA from tomato and other herbaceous plants. Plant Mol. Biol. Rep. 13:207-209.

17. Garcia, I., Lora, J. M., Cruz, J. D. I., Benitez, T., Llobel, A., and Pintor Toro, J. A. 1994. Cloning and characterization of a chitinase (CHIT42) cDNA from the mycoparasitic fungus Trichoderma harzianum. Curr. Genet. 27:83-89.

18. Gegenheimer, P. 1990. Preparation of extracts from plants. Methods Enzymol. 182:174-193.

19. Harman, G. E., Hayes, C. K., Lorito, M., Broadway, R. M., Di Pietro, A., and Trosmo, A. 1993. Chitinolytic enzymes of Trichoderma harzianum: Purification of chitobiosidase and endochitinase. Phytopathology 83:313-318.

20. Hayes, C. K., Klemsdal, S., Lorito, M., Di Pietro, A., Peterbauer, C., Nakasa, J. P., Tronsmo, A., and Harman, G. E. 1994. Isolation and sequence of an endochitinase-encoding gene from a cDNA library of Trichoderma harzianum. Gene 138:143-148.

21. Hildebrand, P. D., Lockhart, C. L., Newbery, R. J., and Ross, R. G. 1989. Resistance of Venturia inaequalis to bitertanol and other demethylationinhibiting fungicides. Can. J. Plant Pathol. 10:311-316.

22. Jerome, M. A. 1965. The cell wall. Pages 49-76 in: The Fungi: An Advanced Treatise. G. C. Ainsworth and A. S. Sussman, eds. Academic Press, NY.

23. Jobling, S. A., and Gehrke, L. 1987. Enhanced translation of chimaeric messenger RNAs containing a plant viral untranslated leader sequence. Nature (Lond.) 325:622-625.

24. Koller, W., Wilcox, W. F., Barnard, J., Jones, A. L., and Braun, P. G. 1997. 
Detection and quantification of resistance of Venturia inaequalis populations to sterol demethylation inhibitors. Phytopathology 87:184-190.

25. Lamb, R. C., Aldwinckle, H. S., Way, R. D., and Terry, D. E. 1979. 'Liberty' apple. HortScience 14:757-758

26. Legrand, M., Kauffmann, S., Geoffroy, P., and Fritig, B. 1987. Biological function of pathogenesis-related proteins: four tobacco pathogenesisrelated proteins are chitinases. Proc. Natl. Acad. Sci. USA 84:6750-6754.

27. Lorito, M., Harman, G. E, Hayes, C. K., Broadway, R. M., Tronsmo, A., Woo, S. L., and Di Pietro, A. 1993. Chitinolytic enzymes produced by Trichoderma harzianum: Antifungal activity of purified endochitinase and chitobiosidase. Phytopathology 83:302-307.

28. Lorito, M., Hayes, C. K., Di Pietro, A., Woo S. L., and Harman, G. E. 1994. Purification, characterization, and synergistic activity of a glucan 1,3- $\beta$-glucosidase and an $N$-acetyl- $\beta$-glucosaminidase from Trichoderma harzianum. Phytopathology 84:398-405.

29. Lorito, M., Woo S. L., D’Ambrosio, M., Harman, G. E, Hayes, C. K., Kubicek, C. P., and Scala, F. 1996. Synergistic interaction between cell wall degrading enzymes and membrane affecting compounds. Mol. PlantMicrobe Interact. 9:206-213.

30. Lorito, M., Woo, S. L., Fernandez, I. G., Colucci, G., Harman, G. E., Pintor-Toro, J. A., Filippone, E., Muccifora, S., Lawrence, C. B., Zoina, A., Tuzun, S., and Scala, F. 1998. Genes from mycoparasitic fungi as a source for improving plant resistance to fungal pathogens. Proc. Natl. Acad. Sci. USA 95:7860-7865.

31. MacHardy, W. E. 1996. Apple Scab: Biology, Epidemiology, and Management. The American Phytopathological Society, St. Paul, MN.

32. Merwin, I. A., Brown, S. K., Rosenberger, D. A., Cooley, D. R., and Berkett, L. P. 1994. Scab-resistant apples for the northeastern United States: New prospects and old problems. Plant Dis. 78:4-10.

33. Nagel, R., Elliott, A., Masel, A., Birch, R. G., and Manners, J. M. 1990. Electroporation of binary Ti plasmid vector into Agrobacterium tumefaciens and Agrobacterium rhizogenes. FEMS Microbiol. Lett. 67:325-328.
34. Norelli, J. L, Aldwinckle, H. S, Beltran, L. D., and Jaynes, J. M. 1994. Transgenic 'Malling 26' apple expressing the attacin E gene has increased resistance to Erwinia amylovora. Euphytica 77:123-128.

35. Norelli, J. L., Mills, J. A., and Aldwinckle, H. S. 1996. Leaf wounding increases efficiency of Agrobacterium-mediated transformation of apple. HortScience 31:1026-1027.

36. Odell, J. T., Nagy, F., and Chua, N. H. 1985. Identification of DNA sequences required for activity of the cauliflower mosaic virus $35 \mathrm{~S}$ promoter. Nature (Lond.) 313:810-812.

37. Parisi, L., Lespinasse, Y., Guillaumes, J., and Kruger, J. 1993. A new race of Venturia inaequalis virulent to apples with resistance due to the $V f$ gene. Phytopathology 83:533-537.

38. Patil, V. R., and Widholm, J., M. 1997. Possible correlation between increased vigor and chitinase activity expression in tobacco. J. Exp. Bot. 48: 1943-1950.

39. Sahai, A. S., and Manocha, M. S. 1993. Chitinases of fungi and plants: their involvement in morphogenesis and host-parasite interaction. Microbiol. Rev. 11:317-338.

40. Schickler, H., and Chet., I. 1997. Heterologous chitinase gene expression to improve plant defense against phytopathogenic fungi. J. Ind. Microbiol. Biotechnol. 19:196-201.

41. Tronsmo, A., and Harman, G. E. 1993. Detection and quantification of $N$-acetyl- $\beta$-D-glucosaminidase, chitobiosidase, and endochitinase in solutions and on gels. Anal. Biochem. 208:74-79.

42. Wong, K. W., Harman, G. E., Norelli, J. L., Gustafson, H. L., and Aldwinckle, H. S. 1999. Chitinase-transgenic lines of 'Royal Gala' apple showing enhanced resistance to apple scab. Acta Hortic. 484:595-599.

43. Yepes, L. M., and Aldwinckle, H. S. 1993. Pathogenesis of Venturia inaequalis on shoot-tip cultures and on greenhouse-grown apple cultivars. Phytopathology 83:1155-1162.

44. Zikakis, J. P. 1984. Chitin, Chitosan and Related Enzymes. Academic Press, New York. 